\title{
Rumen Parameters of West African Dwarf (WAD) Goats Fed Cassava Peels- Poultry Manure Concentrate Supplements
}

\author{
Ajagbe, A.D.; Okpe, A.A.; Abdulhamid, A.A. and Abalaka E.O
}

Department of Animal Production Kogi State University Anyigba

*Corresponding Author: adekunleajagbe1@gmail.com

\begin{abstract}
This experiment was conducted to evaluate the effects of supplementing cassava peels with dried poultry manure on rumen parameters of West African Dwarf (WAD) goats. Twenty growing West African Dwarf bucks aged 5-7 months with an average body weight of 5.05 $\pm 0.02 \mathrm{~kg}$ were used in a completely randomized experiment. The goats were randomly assigned to one of the five dietary treatments which consisted of processed cassava peels and dried poultry manure in different ratios of 100:0(diet 1), 50:50(diet 2), 60:40(diet 3), 70:30(diet 4) and 80:20(diet 5). Data collected were subjected to analysis of variance. The result indicated that among all the parameters examined, acetic acid was significantly $(P<0.05)$ influenced by dietary treatments at the start of the experiment and ranged from $20.77 \mathrm{~mol} / 100 \mathrm{ml}$ to $26.18 \mathrm{~mol} / 100 \mathrm{ml}$ while $\mathrm{pH}$ and acetic acid were significantly $(P<0.05)$ influenced at the end of the trial. There was a significant $(P<0.05)$ increase in value of acetic acid across the treatments at the end of the experiment. The study revealed that supplementing the diets of goats with cassava peels and poultry manure has the potentials of meeting the nutritional needs of the animal without negative effects on the rumen parameters.
\end{abstract}

Keywords - Cassava Peels, Poultry manure, WAD, Rumen parameters.

\section{INTRODUCTION}

Inadequate availability of animal feed in terms of quality and quantity is a major challenge for livestock production, sustainability and profitability (Ajagbe et al., 2015, Abo zeid et al., 2017). Natural herbage which used to serve as feed stuffs for ruminant often decline in quality and quantity during dry season. More so, using cereals grains in ruminant diets is considered to be a direct conflicting competition between livestock production and human nutrition (Abo zeid et al., 2017). As a result, livestock producer especially ruminant both at smallholders and commercial production levels have to seek for alternative feed resources without sacrificing quality of feed and productive performance of the animals. As a result of the fore going research efforts have been shifted to use of cheap sources of agro- based industrial by- product and organic waste as supplements in ruminant production. Parts of these feed resources are cassava peel and poultry manure. FAO (2005), stated that productive feeds for the ruminant livestock could be prepared with various components of cassava plant such as tuber, peels, pulp etc as non-structural carbohydrates and fermentable energy source. Dried poultry manure would provide fermentable nitrogen required for optimum utilization of the readily fermentable carbohydrates of the cassava peels in the concentrate diets (Yousuf et al., 2013). Ruminant animals are unique in their feeding status based on the physiology of their rumen. Therefore, adequate feeding to meeting the nutritional need of the rumen microbes plays vital role in ruminant animal nutrition. Mohammed and Chaury, (2008) indicated that rumen fermentation products such as volatile fatty acids are essentials nutrients to meet the demand of rumen microbes and animals body build up. This study was carried out to evaluate rumen parameters of growing West African Dwarf goats fed cassava peel meal and dried poultry manure concentrate supplements.

\section{MATERIALS AND METHODS}

The experiment was carried out at the Sheep and Goat Unit of Department of Animal Production, Kogi State, University, Anyigba, Kogi State. Anyigba is located in the derived 
Savannah of Nigeria on Latitude $7^{0} 15^{1}$ and $7^{0} 29^{1} \mathrm{~N}$ of the equator and Longitude $7^{0} 11^{1}$ and $7^{0} 32^{1} \mathrm{E}$ of the Greenwich meridian (Ifatimehin et al., 2006). The wet season spreads over a minimum of seven (7) months and it extends from late April to October with the dry season spanning from November to March with an appropriate of five (5) months. Rainfall here is highly seasonal and September is the rainiest month with short dry season (break) in August with a mean annual rainfall ranging from $150 \mathrm{~mm}$ to $250 \mathrm{~mm}$. The area has a humidity of about $70 \%$ on the average and a mean annual temperature of $27^{\circ} \mathrm{C}(\mathrm{Iji}, 2007)$. The area is characterized by luxuriant growth of many tall grass species like Gambia grass (Andropogon tectorium, Andropogon gayanus), Elephant grass (Pennisetum purpuerm), Guinea grass (Panicum maximum) and some short grasses (Ifatimehin et al., 2006). Fresh cassava peels, free from stumps were collected and grated before being subjected to hydraulic press for dewatering. The dewatered peels were then pulverized and sieved to obtain the coarse mash, which was then sun-dried for 2-3days before being loaded into bags for feeding animals (Ajagbe et al., 2019). Cassava foliage was harvested fresh and sun dried until the leaves became brittle for milling.

\section{Experimental Procedure}

A total of twenty (20) West African Dwarf bucks of about 5-7 months, having an initial weight between $5.00 \mathrm{~kg}$ to $6.50 \mathrm{~kg}$ were obtained from goat producers within Anyigba town for 60 days experiment. Goats were housed semiintensively in well-ventilated wooden cages in the pens. The cages were built on wooden stands, $40 \mathrm{~cm}$ from the floor. Before the goats were brought in, the pen was cleaned, washed and disinfected with izal solution two weeks prior to arrival. The entire goat house was fumigated using strong fumigants (Dimethoate 40\% and Action 40\%) against fleas. Prophylactic treatments were given to all the goats: they were dewormed and vaccinated against pests des petits ruminantae (PPR). Treatment against ecto-parasites was done with the use of Amitraz solution. Multivitamin was also administered to boost appetite. The goats were randomly distributed to 5 treatments of 4 animals each. A 14 days adjustment period was allowed for the goats before data collection commenced. Concentrate supplements were fed daily on $5 \%$ body weight after 5-7 hour grazing. The weighing of the goats was done weekly to determine the weight gain.

The goats were randomly assigned to five treatments with four replicates in a Complete Randomize Design (CRD). $100 \%$ treated cassava peel was allotted to $\mathrm{T} 1$ as the control diet, $50 \%$ untreated cassava peel $+50 \%$ cassava foliage was allotted to diet $1,60 \%$ untreated cassava peel $+40 \%$ cassava foliage was allotted to diet 2, 70\% cassava peel $+40 \%$ cassava foliage diet 3 and $80 \%$ Cassava peel $+20 \%$ cassava foliage allotted to diet 4 respectively. Goats were fed daily supplementary diets on 5\% body weight after about 5-6 hours daily grazing.

\section{Rumen Fluid Collection}

Rumen liquor samples were collected from two animals per treatment at the start and end of the feeding trial with the use of stomach tube as describe by (Wanapat and Khampa2007) $20 \mathrm{ml}$ of the rumen liquor was collected from two replicates per treatment into sample bottles, the rumen $\mathrm{pH}$ of each sample was determined immediately after collection using the Jenway $\mathrm{pH}$ meter, model 3150 and immediately stored in the freezer at $-5^{\circ} \mathrm{C}$. until analysis. Rumen fluid sample were strained through four layers of cheese cloth.

\section{Laboratory Analysis}

Proximate composition of the experimental diets was analyzed according to the methods of Association of Official Analytical Chemists (AOAC) (2005). Individual volatile fatty acids production was determined using gas chromatography (Mabrahtu and Tenaye, 1997).

\section{Statistical Analysis}

Data collected were subjected to one way analysis of variance (ANOVA) SPSS (20). The Mean separations were compared using Duncan's Multiple Ranged Test.

Table 1: Gross Composition of experimental diet (\%)

\begin{tabular}{llllll}
\hline Ingredients & T1 & T2 & T3 & T4 & T5 \\
\hline Cassava Peels & 100 & 50 & 60 & 70 & 80 \\
Cassava Foliage & - & 50 & 40 & 30 & 20 \\
Total & 100 & 100 & 100 & 100 & 100 \\
\hline
\end{tabular}




\section{RESULTS}

Nutrient composition of supplementary diets is shown in Table 2. Dry matter (DM) ranged between $89.16 \%$ and $89.90 \%$, diet 2 had higher value than other treatments. Observed value for crude protein ranged between $11.11 \%$ and $12.44 \%$ with diet 2 having the highest value. Values obtained for crude fibre indicated that diet 2 had higher value while diet 5 had the lowest value.Ash contents was higher in diet $2(3.19 \%)$ while diet 1 had higher nitrogen free extract $(86.12 \%)$.

Table 2: Nutrient Composition of Cassava peel- poultry manure concentrate supplement

(\%)

\begin{tabular}{lccccc}
\hline Nutrient & Diet 1 & Diet 2 & Diet 3 & Diet 4 & Diet 5 \\
\hline Dry Matter & 89.16 & 89.90 & 89.76 & 89.60 & 89.46 \\
Organic Matter & 86.66 & 82.53 & 86.71 & 86.69 & 86.68 \\
Crude Protein & 5.27 & 12.44 & 11.94 & 11.53 & 11.11 \\
Crude Fibre & 4.45 & 6.34 & 5.96 & 4.59 & 5.20 \\
Ether Extract & 0.82 & 0.74 & 0.75 & 0.77 & 0.79 \\
Ash & 2.50 & 3.19 & 3.05 & 2.91 & 2.78 \\
Nitrogen Free Extract & 86.12 & 72.29 & 73.30 & 74.82 & 75.12 \\
\hline
\end{tabular}

Rumen parameters of West African Dwarf goats fed cassava peels and dried poultry manure concentrate supplements is shown in Table 3. At the start of the experiment, acetic acid and butyric acid were significantly $(\mathrm{P}<0.05)$ influenced by dietary supplements while $\mathrm{pH}$, lactic acid and propionic acid were not $(\mathrm{P}>0.05)$ significantly different among the treatments. Acetic acid ranged between $20.77 \mathrm{~mol} / 100 \mathrm{ml}$ and $26.18 \mathrm{~mol} / 100 \mathrm{lml}$ with diet 3 having higher value. Propionic acid differed $(\mathrm{P}<0.05)$ among the treatments ranging from 19.15 to $22.14 \%$ following similar trend of higher value in diet 3. The values of $\mathrm{pH}$ ranged from 6.48 to 7.14 , lactic acid
(47.43mol/100ml-48.18mol/100ml).All parameters examined at the end of the trial were not significantly different $(\mathrm{P}>0.05)$ among the dietary treatments except $\mathrm{pH}$ and acetic acid. Higher value of acetic acid was observed for diet 2 $(38.70 \mathrm{~mol} / 100 \mathrm{ml})$. Values obtained for diet $1,3,4$ and 5 were similar but different from diet 2 . Values of $\mathrm{pH}$ significantly ranged between 6.64 and $7.11 \mathrm{pH}$. Lactic acid and propionic acid had higher values for diet $4(14.62 \mathrm{~mol} / 100 \mathrm{ml}$ and $20.63 \mathrm{~mol} / 100 \mathrm{ml}$ ) respectively while butyric acid had higher value for diet $2(22.92 \mathrm{~mol} / 100 \mathrm{ml})$.

Table 3: Rumen parameters of WAD goats fed cassava peels-dried poultry concentrate

supplements.

\begin{tabular}{|c|c|c|c|c|c|c|c|}
\hline \multirow[b]{2}{*}{ Parameters } & \multirow[b]{2}{*}{$\mathrm{T} 1$} & \multirow[b]{2}{*}{$\mathrm{T} 2$} & \multicolumn{3}{|l|}{ Diets } & \multirow[b]{2}{*}{ SEM } & \multirow[b]{2}{*}{ LOS } \\
\hline & & & $\mathrm{T} 3$ & $\mathrm{~T} 4$ & $\mathrm{~T} 5$ & & \\
\hline \multicolumn{8}{|l|}{ At the start of the experiment } \\
\hline $\mathrm{pH}$ & 6.52 & 6.48 & 7.14 & 6.72 & 6.49 & 0.12 & NS \\
\hline Lactic acid $(\mathrm{mol} / 100 \mathrm{ml})$ & 47.43 & 48.06 & 48.12 & 47.97 & 47.43 & 0.34 & NS \\
\hline Acetic Acid (mol/100ml) & $24.15^{\mathrm{ab}}$ & $25.40^{\mathrm{a}}$ & $26.18^{\mathrm{a}}$ & $20.77^{\mathrm{b}}$ & $25.11^{\mathrm{a}}$ & 0.72 & $*$ \\
\hline Propionic Acid (mol/100ml) & 20.12 & 19.50 & 22.06 & 20.90 & 20.33 & 0.41 & NS \\
\hline Butyric Acid (mol/100ml) & $19.46^{\mathrm{ab}}$ & $19.39^{\mathrm{ab}}$ & $22.14^{\mathrm{a}}$ & $18.54^{\mathrm{b}}$ & $19.15^{\mathrm{b}}$ & 0.48 & $*$ \\
\hline \multicolumn{8}{|l|}{ At the end of the Experiment } \\
\hline $\mathrm{pH}$ & $6.82^{\mathrm{ab}}$ & $6.64^{c}$ & $7.11^{\mathrm{a}}$ & $6.72^{c}$ & $7.01^{\mathrm{ab}}$ & 0.63 & $*$ \\
\hline Lactic acid (mol/100ml) & 14.14 & 13.83 & 14.26 & 14.62 & 14.30 & 0.11 & NS \\
\hline Acetic Acid (mol/100ml) & $28.17^{\mathrm{b}}$ & $38.70^{\mathrm{a}}$ & $29.09^{\mathrm{b}}$ & $28.22^{\mathrm{b}}$ & $29.38^{\mathrm{b}}$ & 1.35 & $*$ \\
\hline Propionic Acid (mol/100ml) & 20.31 & 18.82 & 19.47 & 20.63 & 19.43 & 0.31 & NS \\
\hline Butyric Acid ( mol/100ml) & 20.59 & 22.92 & 19.16 & 22.17 & 21.15 & 0.56 & NS \\
\hline
\end{tabular}

ISSN: 2456-1878 


\section{DISCUSSION}

Dry matter values of the experimental diets ranged from 89.16\%- 89.90\%. Crude protein values decreased with decrease ratio of poultry manure supplementation. The dry matter content in this study was higher than $85.00 \%$ to $88.50 \%$ reported by Yusuf et al. (2013). The dry matter content was higher than 83.23-85.60\% reported by Ajagbe et al. (2020) in their study with West African Dwarf goats fed nitrogen supplemented cassava peel meal. Organic matter content varied between $82.53 \%$ and $86.77 \%$. These values are higher than $77.86-80.53$ reported by Ajagbe et al. (2020). Crude protein content was lower than $10.00 \%$ to16.0\% reported by Yusuf et al. (2013) for their study with young WAD goats fed broiler litter waste and urea based diets. Values of crude fibre content ranged from $6.20 \%$ to 9.34\%. These values were lower than $5.50 \%$ to $25,00 \%$ reported by Bello and Tsado (2013). Ether extract content was lower compared to $5.00 \%$ to $20.00 \%$ reported by Bello and Tsado (2013) for their study on Yankasa rams fed sorghum stover supplemented with graded levels of dried poultry droppings based diets. Ash content values in this study were lower than $10.50 \%-10.89 \%$ reported by Bello (2017) for finger millet straw supplemented with varying levels of dried poultry dropping based diets. Nitrogen free extract in this study was lower than $7.29 \%-14.56 \%$ reported by Ukanwoko and Ibeawuchi (2009). Variation in nutrient composition of experimental diets might be attributed to different feed ingredients, processing methods of feed ingredients, soil condition on which the feed materials used was harvested and other factors such as climatic factors of the location etc.

All the $\mathrm{pH}$ values recorded fell within the reported values $(6.00-7.20 \mathrm{pH})$ suitable for the growth and activities of rumen microbes (Jallow and Hsia, 2011). Kamra (2005) stated that a range of $6.0-6.9 \mathrm{pH}$ can facilitate optimum growth of rumen bacteria. Among the parameters examined at the start of the experiment for volatile fatty acids, acetic acid and butyric acid were significantly $(\mathrm{P}<0.05)$ influenced by treatment diets. Values of acetic acid for diets 1,2,3 and 5 were similar but different from diets 1 . The values of acetic obtained in this study were higher for diet 3 . These values were lower compared to the values $(52.5-68.9 \mathrm{~mol} / 100 \mathrm{ml}$ reported by Abo zeid et al. (2017). The values were also lower than $42.03 \mathrm{~mol} / 100 \mathrm{ml}-46.65 \mathrm{~mol} / 100 \mathrm{ml}$ reported by Okoruwa et al. (2016). Butyric acid values were higher than 8.80-12.47mol/100ml reported by Adebayo et al. (2017) for their study on rumen fermentation characteristics of West
African Dwarf goats fed enzyme supplemented total mixed ration in the dry season. The values were higher than $16.77 \mathrm{~mol} / 100 \mathrm{ml}-18 \mathrm{~mol} / 100 \mathrm{ml}$ reported by Puga et al. (2001) for sheep fed controlled release urea supplements. Variations in the values might be attributed to physical fibrousness, levels of starch content and carbohydrate solubility of the different dietary treatments used in different studies conducted. Aside from lactic acid, values acetic acids obtained indicate that acetic acid predominates the volatile fatty acid production followed by propionic and butyric acid. Values of $\mathrm{pH}$ obtained were comparable to 6.47- 6.67 reported by Puga et al. (2001) but higher than 5.97-6.17 reported by Oni et al. (2017). Lactic acid values obtained at the start of the trial were higher than $5-21 \mathrm{~mol} / 1$ ooml reported by Suarez et al. (2006). Values of propionic acid obtained were lower than $21.6 \mathrm{~mol} / 100 \mathrm{ml}-28.8 \mathrm{~mol} / 100 \mathrm{ml}$ reported by Suarez et al (2006) in their study on effects of different levels of roughage- concentrate dietary treatments on rumen fermentation characteristics of sheep. The difference in values obtained by different authors might be attributed to nature of the diets fed to the animals as well as the chemical composition of the test ingredients.

At the end of the study, values of $\mathrm{pH}$ obtained were higher than 6.22-7.01 reported by Njidda et al. (2016) on rumen fermentation parameters of Red Sokoto goats fed cowpea husk replacing Daniella oliveri leaf. The values are comparable to the normal value range of 6.0-7.0 reported by Petrovski (2017). The observed non- significant value of the volatile fatty acids examined indicated that lactic acid and acetic acid reduced across the treatments while propionic acid increased in diet1. Butyric acid values were higher at the end of the study for diet 1,2, 4 and 5. The increased value of butyric acid might be attributed to levels of carbohydrate degradation of the cellulosic substances present in the feed. Higher values of propionic were observed in diet 3 at the start of the study than at the end of the trial.

\section{CONCLUSION}

Based on the results obtained in this study, supplementing the diets of grazing growing West African Dwarf goats with cassava peels and dried poultry manure has the potentials of meeting the nutritional needs of the animals without adverse effects on the rumen parameters.

\section{ACKNOWLEDGEMENT}

The authority of Livestock Teaching and Research Farm, Kogi State University, Anyigba, Nigeria is acknowledged for 
providing support for this study. The effort of all the technical staff of the department of Animal Production, Kogi State University Anyigba, is deeply appreciated.

\section{CONFLICT OF INTEREST}

The authors declared that they have no conflicts of interest with the contents of this article.

\section{REFERENCES}

[1] Adebayo, K.O, Aderinboye, R.Y, Isah, O.A and Onwuka C.F. I. (2017). Rumen fermentation characteristics of West African Dwarf goats fed enzyme supplemented total mixed ration in the dry season. Animal Research International 14(3): 2867 2875.

[2] Ajagbe A.D, Oyewole, B.O, Aribido, S.O and Oyibo A. (2020). Nutrient Intake of West African Dwarf (WAD) Goats Fed Cassava Peels Supplemented with Nitrogen Sources. GSC Biological and Pharmaceutical Sciences 12(1): 189-195.

[3] Ajagbe D.A., Aribido S.O., Oyewole B.O and Egwuje C.O. (2019). Hematology and Serum Biochemistry of Growing West African Dwarf Goats Fed Cassava Peel with Supplemental Nitrogen Sources. Agricultural Extension Journal, 3(3).1-6.

[4] Ajagbe, A.D., Kibon, A. and Oyewole B.O (2015). Performance, Milk Yield and Composition of Grazing Sahel does Supplemented with Cottonseed cake-Maize Bran Mixture. Nsuk Journal of Science and Technology (NJST) 5 (2): 6-10

[5] Bello A.A. (2017). Feed Intake and Nutrient Digestibility of KonkanKanyal Goats Fed Finger Millet Straw Supplemented with Varying Levels of Dried Poultry Dropping Based Diets. Asian Journal of Animal Science.11(5):230-236.

[6] Bello, A.A. and. Tsado, D.N. (2013). Feed intake and nutrient digestibility of growing Yankasa rams fed sorghum stover supplemented with graded levels of dried poultry droppings based diet. Asian Journal Animal Science 7: 56-63

[7] FAO (2005).Food and Agricultural Organization. Annual Report, 2005.

[8] Ifatimehin, O.O. Musa, S.D. and Adeyemi, J.O. (2006). Analysis of the changing land use and its impact on the environment of Anyigba Town, Nigeria. Journal of Sustainable Development in Africa, 10(4): 45-50.

[9] Iji, M.E. (2007).An assessment of water demand and supply in Anyigba, Kogi State.B.Sc. Research Project submitted to the Department of Gegraphy and Planning Kogi State University,Anyigba, Nigeria.

[10] Jallow, D. B. and Hsia, L .C. (2011). Effect of six feed supplement on ruminal degradation characteristics and amino acid profile of sheep. International Journal of Animal and Veterinary advances, 3(5): 367-373

[11] Kamra D. N. (2005). Rumen, Rumen bacteria, Protozoa, Buffaloes, Sheep, Tannins, Goats, Anaerobic bacteria. Current Science Association 89, No. 1

[12] Mohammed R. and Chaundry A.S., (2008) Methods to study Degradation of Ruminant Feeds Nutrition, Res Rev, 21, 68-81.

[13] Njidda A.A., Alabi O.J. and Olafadehan O.A., (2016).Rumen and Energy Utilization of Red Sokoto Goats fed Cowpea Husk substituting Daniella Oliverri Foliage, Journal of Animal Production and Resources 28(1), 205-214

[14] Okoruwa, M.I., Bamigboye F. O. and Agbadu, A. (2016) Rumen metabolites and thermo- physiological response of West African dwarf sheep as influenced by ficus foliage with differently processed breadfruit meals. Global Journal of Agricultural Research Vol.4, No.5, pp.28-38.

[15] Oni, A.O., Oluwayemisi, A., Adebayo, K.,Sowande, O.S., Ipo su, S., and Onwuka, C.F.I.(2017).

[16] Effects of supplementing cassava peels with cassava leaves and cowpea haulms on therumen environment and blood profile parameters of West African dwarf goats Archivos de Zootecnia, vol. 66, núm. 255, pp. 397-404.

[17] Petrovski K.R (2017). Assessment of the rumen fluid of a bovine patient. Journal of dairy \& veterinary sciences 2(3) 1-7

[18] Puga, D.C. Galina, H.M. PerezGil R.F Sangine G.L Aguilera., B.A.,Haenlein G.F.W.(2001).Effect of a controlled-release urea supplement on rumenfermentation in sheep fed a diet of sugar cane tops(Saccharum ofÆcinarum), corn stubble (Zea mays) and King grass (Pennisetum purpureum). Small Ruminant Research 39: 269 276 .

[19] Suárez, B., Van Reenen, C.G., Gerrits, W.J.J., Stockhofe, N., Van Vuuren, A.M. and Dijkstra,J.(2006).Effects of supplementing concentrates differi ng in carbohydrate compos ition in veal calf diets: II. Rumen development. Journal of Dairy Science. 89:43764386.

[20] Ukanwoko, A.I., And Ibeawuchi, J. A. (2009) Nutrient intake digestibility of West African Dwarf bucks fed poultry waste cassava peels based diets. Pakistan Journal of Nutrition, 8(9) :1461 - 1464.

[21] Wanapat M, Khampa S. (2007). Effect of levels of supplementation of Concentrate containing high levels of cassava chip on rumen ecology, microbial $\mathrm{N}$ supply and digestibility of nutrients in beef cattle. Asian-Australian Journal of Animal Science 20: 81.

[22] Yusuf, A.O., Ekunseitan, D.A., Bawala, T.O., Ayoola, A.A And Ogunnowo, A.E. (2013). Impact of broiler litter waste and urea based diets on performance of young West African Dwarf goats. The Pacific Journal of Sceince and Technology 14(2) 425-432. 